\title{
TECHNOLOGY DEMONSTRATION OF SLUDGE MASS REDUCTION VIA ALUMINUM DISSOLUTION: GLASS FORMULATION PROCESSING WINDOW PREDICTIONS FOR SB5
}

K.M. Fox

T.B. Edwards

D.K. Peeler

December 2007

Process Science and Engineering

Savannah River National Laboratory

Aiken, SC 29808

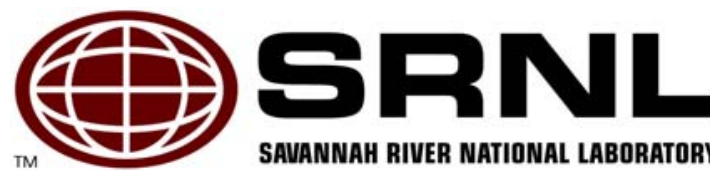


WSRC-STI-2007-00690

Revision 0

\section{DISCLAIMER}

This report was prepared by Washington Savannah River Company (WSRC) for the United States Department of Energy under Contract No. DE-AC09-96SR18500 and is an account of work performed under that contract. Neither the United States Department of Energy, nor WSRC, nor any of their employees makes any warranty, expressed or implied, or assumes any legal liability or responsibility for the accuracy, completeness, or usefulness, of any information, apparatus, or product or process disclosed herein or represents that its use will not infringe privately owned rights. Reference herein to any specific commercial product, process, or service by trademark, name, manufacturer or otherwise does not necessarily constitute or imply endorsement, recommendation, or favoring of same by WSRC or by the United States Government or any agency thereof. The views and opinions of the authors expressed herein do not necessarily state or reflect those of the United States Government or any agency thereof.

\section{Printed in the United States of America \\ Prepared For U.S. Department of Energy}

The Savannah River National Laboratory is operated for the U.S. Department of Energy by Washington Savannah River Company. 


\section{TECHNOLOGY DEMONSTRATION OF SLUDGE MASS REDUCTION VIA ALUMINUM DISSOLUTION: GLASS FORMULATION PROCESSING WINDOW PREDICTIONS FOR SB5}

K.M. Fox

T.B. Edwards

D.K. Peeler

December 2007

Process Science and Engineering

Savannah River National Laboratory

Aiken, SC 29808

Prepared for the U.S. Department of Energy Under

Contract Number DEAC09-96SR18500

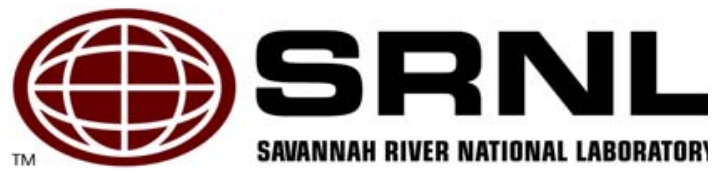


WSRC-STI-2007-00690

Revision 0

\section{REVIEWS AND APPROVALS}

\section{AUTHORS:}

K.M. Fox, Process Science and Engineering Section

Date

T.B. Edwards, Statistical Consulting Section

Date

D.K. Peeler, Process Science and Engineering Section

Date

\section{TECHNICAL REVIEWERS:}

J.D. Newell, Process Science and Engineering Section

Date

F.C. Raszewski, Process Science and Engineering Section

Date

\section{APPROVERS:}

C.C. Herman, Manager, Process Engineering Technology Group

Date

R.E. Edwards, Manager, Process Science and Engineering Section

Date

J. Stuberfield, Project Owner - Sludge Mass Reduction Program

Date

Technology Development and Tank Closure - Liquid Waste Organization

P.C. Suggs, DOE - SRS/AMWDP

Technology Development and Tank Closure - Liquid Waste Organization 
WSRC-STI-2007-00690

Revision 0

\section{EXECUTIVE SUMMARY}

Composition projections for Sludge Batch 5 (SB5) were developed, based on a modeling approach at the Savannah River National Laboratory (SRNL), to evaluate possible impacts of the Al-dissolution process on the availability of viable frit compositions for vitrification at the Defense Waste Processing Facility (DWPF). The study included two projected SB5 compositions that bound potential outcomes (or degrees of effectiveness) of the Al-dissolution process, as well as a nominal SB5 composition projection based on the results of the recent Aldissolution demonstration at SRNL. The three SB5 projections were the focus of a two-stage paper study assessment. A Nominal Stage assessment combined each of the SB5 composition projections with an array of 19,305 frit compositions over a wide range of waste loading (WL) values and evaluated them against the DWPF process control models. The Nominal Stage results allowed for the down-selection of a small number of frits that provided reasonable projected operating windows (typically 27 to $42 \mathrm{wt} \% \mathrm{WL}$ ). The frit/sludge systems were mostly limited by process related constraints, with only one system being limited by predictions of nepheline crystallization, a waste form affecting constraint. The criteria applied in selecting the frit compositions somewhat restricted the compositional flexibility of the candidate frits for each individual SB5 composition projection, which may limit the ability to further tailor the frit for improved melt rate.

Variation Stage assessments were then performed using the down-selected frits and the three SB5 composition projections with variation applied to each sludge component. The Variation Stage results showed that the operating windows were reduced in width, as expected when variation in the sludge composition is applied. However, several of the down-selected frits exhibited a relatively high degree of robustness to the applied sludge variation, providing WL windows of approximately 30 to $39 \mathrm{wt} \%$. The maximum WLs were limited by processing constraints, liquidus temperature and low viscosity, rather than a waste form affecting constraint (e.g., nepheline crystallization) in the Variation Stage assessments.

These paper study assessments have identified candidate frits which, when combined with the SRNL projected SB5 compositions after Al-dissolution, have projected operating windows that should be reasonable for DWPF processing. As more information is obtained on the SB5 composition to be processed in DWPF, including the actual $\mathrm{Al}$ removed and Tank 7 mass transferred, additional paper study assessments will be performed as well as experimental frit development studies. The frits identified in this study provide insight into potential processing windows but are not the recommended frits for SB5. No information regarding melt rate can be inferred from the paper study results. Experimental studies to evaluate this critical factor in DWPF processing must be performed on the best SB5 projection before a frit recommendation could be made for any projected sludge composition. 


\section{TABLE OF CONTENTS}

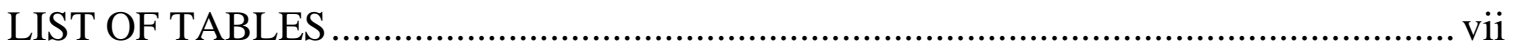

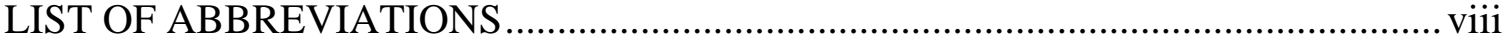

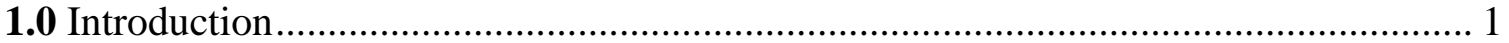

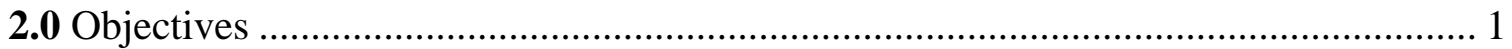

3.0 Sludge Batch 5 Composition Projections ............................................................... 2

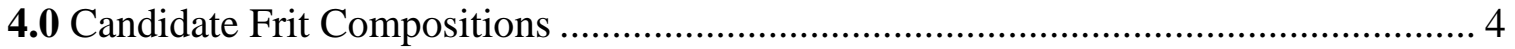

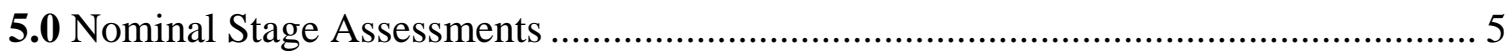

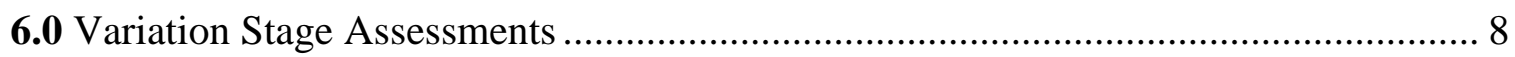

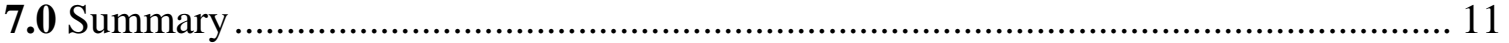

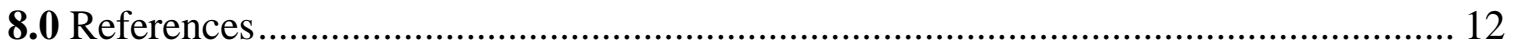

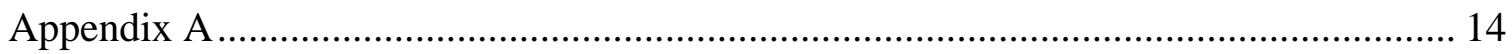




\section{LIST OF TABLES}

Table 3-1. SB5 composition projections as a function of Gibbsite/Boehmite partitioning............ 3

Table 3-2. SB5 composition projection (SB5 Case F) based on 39\% dissolution of aluminum.

Cases B and C are included for comparison. ........................................................................... 4

Table 4-1. Frit components and concentration ranges used to define the frit composition array for

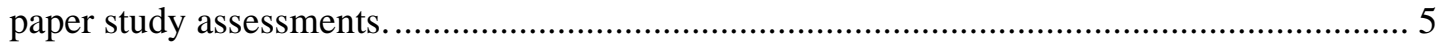

Table 5-1. Candidate frits for SB5 down-selected from the Nominal Stage results....................... 6

Table 5-2. Summary of Nominal Stage results for SB5 Case B with the candidate frits............... 7

Table 5-3. Summary of Nominal Stage results for SB5 Case C with the candidate frits.............. 7

Table 5-4. Summary of Nominal Stage results for SB5 Case F with the candidate frits. .............. 7

Table 6-1. Compositions of SB5 Cases B, C and F with variation applied.................................. 8

Table 6-2. Summary of Variation Stage results for SB5 Case B with the candidate frits.............. 9

Table 6-3. Summary of Variation Stage results for SB5 Case C with the candidate frits.............. 9

Table 6-4. Summary of Variation Stage results for SB5 Case F with the candidate frits. ............. 9 


\section{LIST OF ABBREVIATIONS}

$\begin{array}{ll}\text { CPC } & \text { Chemical Process Cell } \\ \text { DOE } & \text { Department Of Energy } \\ \text { DWPF } & \text { Defense Waste Processing Facility } \\ \text { EVs } & \text { Extreme Vertices } \\ \text { hFrit } & \text { high concentration of frit components } \\ \text { highv } & \text { high viscosity } \\ \text { Homg } & \text { homogeneity } \\ \text { lowv } & \text { low viscosity } \\ \text { LWO } & \text { Liquid Waste Organization } \\ \text { MAR } & \text { Measurement Acceptability Region } \\ \text { Neph } & \text { Nepheline crystallization } \\ \text { NL } & \text { Normalized Leachate } \\ \text { PCCS } & \text { Product Composition Control System } \\ \text { SB4 } & \text { Sludge Batch } 4 \\ \text { SB5 } & \text { Sludge Batch 5 } \\ \text { SRS } & \text { Savannah River Site } \\ \text { TL } & \text { liquidus temperature } \\ \text { WL } & \text { Waste Loading }\end{array}$


WSRC-STI-2007-00690

Revision 0

\subsection{Introduction}

Tank 51 will be blended with Purex sludge from Tank 7 to constitute Sludge Batch 5 (SB5). The Savannah River Site (SRS) Liquid Waste Organization (LWO) is performing low-temperature aluminum-dissolution in Tank 51 to reduce the total mass of sludge solids being fed to the Defense Waste Processing Facility (DWPF). Before this process was performed in the Tank Farm, a radioactive demonstration using a 3 L Tank 51 sludge slurry sample was performed at the Savannah River National Laboratory (SRNL) to determine the effectiveness of the lower temperature process. ${ }^{1}$ The aluminum-dissolved sludge was used to determine potential downstream impacts so that technical issues could be identified before the start of SB5 processing. The potential downstream impacts assessed include the Tank Farm washing and concentration process and the DWPF Chemical Process Cell (CPC) and melter processing envelopes.

Paper study assessments of the composition projections are used to assess various frit options of interest with respect to the projected operating windows (as defined by a waste loading interval) for DWPF. More specifically, for each sludge option, the current Product Composition Control System (PCCS) models ${ }^{2}$ are used to assess the waste loading interval over which glasses would concurrently meet all process and acceptability constraints. Candidate frits are identified that provide a reasonable projected operational window over the anticipated composition region of interest and are robust to anticipated sludge composition variations.

The two stages - Nominal Stage and Variation Stage - traditionally performed by Peeler and Edwards $^{3}$ are employed to assess the various frit/sludge combinations with respect to these key criteria. The Nominal Stage will utilize nominal compositions representing the potential scenarios outlined above (i.e., various amounts of alumina removed from the sludge). This stage identifies candidate frit compositions with respect to their ability to provide a reasonable operating window based solely on a specific nominal composition - no sludge composition variation is considered in this phase.

The Variation Stage assessment is performed to gain insight into the robustness of the candidate frits with respect to potential variation in the Tank Farm's projected sludge composition. This potential variation arises due to uncertainty in the planned blending strategies and tank volumes. A down-select process is used to identify the primary frit candidates from the Nominal Stage results prior to performing the Variation Stage assessment.

\subsection{Objectives}

This report focuses on the impacts to the development of a glass frit to be combined with the reduced $\mathrm{Al}$ concentration sludge for vitrification in the DWPF melter. An assessment is made of the impact of Al-dissolution on the DWPF projected operating windows as defined by the current process control models. The evaluation includes projected SB5 compositions that bound potential outcomes (or degrees of effectiveness) of the Al-dissolution process, as well as a nominal SB5 composition projection based on the outcome of the recent Al-dissolution demonstration at SRNL. ${ }^{1}$

The paper study assessments do not provide any estimates of melt rate performance among the various SB5 projections or frit compositions. Experimental studies will be necessary to provide melt rate information and to guide further decisions on frit compositions for processing at the DWPF. 
This work is Technical Baseline Research and Development for the Department of Energy (DOE) Office of Cleanup Technologies (EM-21) and is performed under task technical and quality assurance plan WSRC-RP-2007-00512. ${ }^{4}$

\subsection{Sludge Batch 5 Composition Projections}

SRNL used a modeling approach to project the anticipated composition of SB5 in support of this study. A detailed description of the modeling methodology is provided in WSRC-STI-200800001. ${ }^{5}$ The model required the following input vectors, which were constructed from available analytical data:

- Tank 51 slurry prior to dilution with Tank 40 supernate $^{6}$

- Tank 40 supernate ${ }^{\mathrm{a}}$

- Tank 7 slurry $^{7}$

- Information on various water leaks, miscellaneous additions, missing ion chromatography data, etc. ${ }^{\mathrm{b}}$

Five composition projection cases were developed for SB5 at the initiation of this study. The five cases project the potential outcomes of the low-temperature Al-dissolution process based on the partitioning of Al between Gibbsite and Boehmite in Tank 51. The amount of Gibbsite was varied between $0 \%$ and $100 \%$ in increments of $25 \%$. The projections assumed a blend of approximately $80 \%$ material from Tank 51 and 20\% material from Tank 40 to constitute the SB5 feed to DWPF (i.e., a 40 inch heel remaining in Tank 40 when the blend occurs). These composition projections for SB5 - the output of the SRNL model - are given in Table 3-1. The projections are listed as a function of Gibbsite/Boehmite partitioning, and labeled SB5 Cases A through E.

\footnotetext{
a Analytical Laboratories report 23Apr07 09:31 Hr

b Tank Farm Spreadsheet 19Jun07
} 
Table 3-1. SB5 composition projections as a function of Gibbsite/Boehmite partitioning.

\begin{tabular}{|c|c|c|c|c|c|}
\hline SB5 Case & $\overline{\mathrm{A}}$ & $\overline{\text { B }}$ & $\overline{c \mathrm{C}}$ & $\overline{\text { D }}$ & $\bar{E}$ \\
\hline Gibbsite (\%) & 0 & 25 & 50 & 75 & 100 \\
\hline Boehmite (\%) & 100 & 75 & 50 & 25 & 0 \\
\hline $\mathrm{Ag}$ & 0.008 & 0.009 & 0.010 & 0.011 & 0.011 \\
\hline $\mathrm{Al}$ & 17.063 & 15.326 & 13.167 & 11.062 & 10.140 \\
\hline $\mathrm{Ba}$ & 0.083 & 0.091 & 0.101 & 0.108 & 0.110 \\
\hline $\mathrm{Ca}$ & 1.163 & 1.273 & 1.404 & 1.505 & 1.539 \\
\hline $\mathrm{Cd}$ & 0.049 & 0.053 & 0.058 & 0.063 & 0.065 \\
\hline $\mathrm{Ce}$ & 0.289 & 0.316 & 0.349 & 0.374 & 0.383 \\
\hline $\mathrm{Co}$ & 0.017 & 0.019 & 0.020 & 0.022 & 0.022 \\
\hline $\mathrm{Cr}$ & 0.233 & 0.255 & 0.281 & 0.301 & 0.307 \\
\hline $\mathrm{Cu}$ & 0.010 & 0.010 & 0.010 & 0.010 & 0.011 \\
\hline $\mathrm{Fe}$ & 14.855 & 16.251 & 17.926 & 19.216 & 19.646 \\
\hline $\mathrm{K}$ & 0.052 & 0.055 & 0.059 & 0.066 & 0.069 \\
\hline $\mathrm{La}$ & 0.127 & 0.139 & 0.153 & 0.164 & 0.168 \\
\hline $\mathrm{Mg}$ & 0.649 & 0.710 & 0.783 & 0.839 & 0.858 \\
\hline $\mathrm{Mn}$ & 3.439 & 3.763 & 4.150 & 4.449 & 4.549 \\
\hline $\mathrm{Na}$ & 18.877 & 18.413 & 17.938 & 18.164 & 18.545 \\
\hline $\mathrm{Ni}$ & 1.960 & 2.144 & 2.365 & 2.535 & 2.592 \\
\hline $\mathrm{P}$ & 0.211 & 0.230 & 0.253 & 0.271 & 0.277 \\
\hline $\mathrm{Pb}$ & 0.019 & 0.020 & 0.022 & 0.024 & 0.025 \\
\hline Pd & 0.001 & 0.001 & 0.001 & 0.001 & 0.001 \\
\hline $\mathrm{Rh}$ & 0.024 & 0.026 & 0.029 & 0.031 & 0.032 \\
\hline $\mathrm{Ru}$ & 0.091 & 0.099 & 0.109 & 0.117 & 0.120 \\
\hline $\mathrm{S}$ & 0.235 & 0.243 & 0.254 & 0.272 & 0.281 \\
\hline $\mathrm{Si}$ & 0.818 & 0.881 & 0.972 & 1.044 & 1.067 \\
\hline $\mathrm{Sr}$ & 0.246 & 0.269 & 0.297 & 0.318 & 0.325 \\
\hline $\mathrm{Ti}$ & 0.014 & 0.015 & 0.017 & 0.018 & 0.019 \\
\hline $\mathrm{U}$ & 5.761 & 6.303 & 6.952 & 7.453 & 7.619 \\
\hline $\mathrm{Zn}$ & 0.012 & 0.013 & 0.013 & 0.015 & 0.015 \\
\hline $\mathrm{Zr}$ & 0.175 & 0.191 & 0.211 & 0.226 & 0.231 \\
\hline Total (wt \%) & 66.483 & 67.120 & 67.906 & 68.681 & 69.026 \\
\hline Tk51 Transfer (kg) & 238,491 & 200,032 & 173,315 & 161,004 & 160,709 \\
\hline TK40 Heel (kg) & 37,733 & 37,733 & 37,733 & 37,733 & 37,733 \\
\hline Tk51 Solids (\%) & 86 & 84 & 82 & 81 & 81 \\
\hline Tk40 Solids (\%) & 14 & 16 & 18 & 19 & 19 \\
\hline
\end{tabular}

The initial results of the 3L Al-dissolution demonstration in the SRNL Shielded Cells facility showed that the $\mathrm{Al}$ was partitioned as approximately $39 \%$ Gibbsite. ${ }^{1}$ This suggested that the SB5 composition would fall between Case B (25\% Gibbsite) and Case C (50\% Gibbsite). The model was run again with $\mathrm{Al}$ partitioned as $39 \%$ Gibbsite and the results are labeled as Case $\mathrm{F}$.

Table 3-2 lists the SB5 Case F composition projection, as well as Cases B and C, which will be the focus of the following paper study assessment. Cases B and $\mathrm{C}$ are included to allow for potential variation from the $39 \%$ Gibbsite value when the actual Al-dissolution process is performed in Tank 51. 
WSRC-STI-2007-00690

Revision 0

Table 3-2. SB5 composition projection (SB5 Case F) based on $39 \%$ dissolution of aluminum. Cases $B$ and $C$ are included for comparison.

\begin{tabular}{|c|c|c|c|}
\hline SB5 Case & $\mathbf{F}$ & B & C \\
\hline Gibbsite (\%) & 39 & 25 & 50 \\
\hline Boehmite (\%) & 61 & 75 & 50 \\
\hline $\mathrm{Ag}$ & 0.009 & 0.009 & 0.010 \\
\hline $\mathrm{Al}$ & 14.38 & 15.326 & 13.167 \\
\hline $\mathrm{Ba}$ & 0.096 & 0.091 & 0.101 \\
\hline $\mathrm{Ca}$ & 1.345 & 1.273 & 1.404 \\
\hline$\overline{\mathrm{Cd}}$ & 0.056 & 0.053 & 0.058 \\
\hline $\mathrm{Ce}$ & 0.331 & 0.316 & 0.349 \\
\hline Co & 0.019 & 0.019 & 0.020 \\
\hline $\mathrm{Cr}$ & 0.266 & 0.255 & 0.281 \\
\hline $\mathrm{Cu}$ & 0.010 & 0.010 & 0.010 \\
\hline $\mathrm{Fe}$ & 17.120 & 16.251 & 17.926 \\
\hline $\mathrm{K}$ & 0.057 & 0.055 & 0.059 \\
\hline $\mathrm{La}$ & 0.145 & 0.139 & 0.153 \\
\hline $\mathrm{Mg}$ & 0.747 & 0.710 & 0.783 \\
\hline $\mathrm{Mn}$ & 3.967 & 3.763 & 4.150 \\
\hline $\mathrm{Na}$ & 17.967 & 18.413 & 17.938 \\
\hline $\mathrm{Ni}$ & 2.249 & 2.144 & 2.365 \\
\hline $\mathrm{P}$ & 0.242 & 0.230 & 0.253 \\
\hline $\mathrm{Pb}$ & 0.021 & 0.020 & 0.022 \\
\hline $\mathrm{Pd}$ & 0.001 & 0.001 & 0.001 \\
\hline $\mathrm{Rh}$ & 0.028 & 0.026 & 0.029 \\
\hline $\mathrm{Ru}$ & 0.104 & 0.099 & 0.109 \\
\hline $\mathrm{S}$ & 0.249 & 0.243 & 0.254 \\
\hline $\mathrm{Si}$ & 0.921 & 0.881 & 0.972 \\
\hline $\mathrm{Sr}$ & 0.286 & 0.269 & 0.297 \\
\hline $\mathrm{Ti}$ & 0.016 & 0.015 & 0.017 \\
\hline $\mathrm{U}$ & 6.612 & 6.303 & 6.952 \\
\hline $\mathrm{Zn}$ & 0.013 & 0.013 & 0.013 \\
\hline $\mathrm{Zr}$ & 0.202 & 0.191 & 0.211 \\
\hline Total (wt \%) & 67.459 & 67.120 & 67.906 \\
\hline Tk51 Transfer (kg) & 268,317 & 200,032 & 173,315 \\
\hline TK40 Heel (kg) & 54,322 & 37,733 & 37,733 \\
\hline Tk51 Solids (\%) & 83 & 84 & 82 \\
\hline Tk40 Solids (\%) & 17 & 16 & 18 \\
\hline
\end{tabular}

\subsection{Candidate Frit Compositions}

An array of frit compositions was developed to combine with SB5 Cases B, C and F in the Nominal Stage assessment. The frit components and their concentration ranges were chosen based on SRNL experience in previous frit development efforts, ${ }^{8-15}$ DWPF operational constraints and practicality issues related to frit production. Frit components and their concentrations defining the frit array are shown in Table 4-1. For each frit composition, the concentration of $\mathrm{SiO}_{2}$ was allowed to float as necessary to accommodate the concentrations of the other oxide components. A total of 19,305 frits were defined using this array. 
WSRC-STI-2007-00690

Revision 0

Table 4-1. Frit components and concentration ranges used to define the frit composition array for paper study assessments.

\begin{tabular}{||c|c|c|c||}
\hline Component & $\begin{array}{c}\text { Min. Concentration } \\
\text { (wt \%) }\end{array}$ & $\begin{array}{c}\text { Max. Concentration } \\
\text { (wt \%) }\end{array}$ & $\begin{array}{c}\text { Increment } \\
\text { (wt \%) }\end{array}$ \\
\hline $\mathrm{B}_{2} \mathrm{O}_{3}$ & 8.0 & 20.0 & 1.0 \\
\hline $\mathrm{CaO}$ & 0.0 & 8.0 & 2.0 \\
\hline $\mathrm{Li}_{2} \mathrm{O}$ & 4.0 & 12.0 & 1.0 \\
\hline $\mathrm{MgO}$ & 0.0 & 4.0 & 2.0 \\
\hline $\mathrm{Na}_{2} \mathrm{O}$ & 2.0 & 12.0 & 1.0 \\
\hline $\mathrm{SiO}_{2}$ & 44.0 & 86.0 & 1.0 \\
\hline
\end{tabular}

\subsection{Nominal Stage Assessments}

Sludge Cases B, C and F were each combined with the array of frits over a waste loading (WL) interval of 25 to $60 \mathrm{wt} \%$ and evaluated against the models currently implemented in the DWPF to constitute the Nominal Stage assessment. Property predictions assessed include those for liquidus temperature (TL), viscosity ( $\eta$ ), durability (normalized leachate for boron, NL[B]), homogeneity (Homg), high viscosity (highv), low viscosity (lowv), high chromia concentration (Cr2O3), high sulfate concentration (SO4), high concentration of frit components (hFrit) and nepheline formation (Neph). ${ }^{\mathrm{a}}$

The constraints associated with minimum $\mathrm{Al}_{2} \mathrm{O}_{3}$ concentrations in glass were also used in these assessments. Current PCCS criteria dictate that the $\mathrm{Al}_{2} \mathrm{O}_{3}$ content in the glass must be at least 3 wt $\%$ (not including uncertainties). For glasses containing more than 3 wt $\% \mathrm{Al}_{2} \mathrm{O}_{3}$ but less than $4 \mathrm{wt} \%$, there is an additional constraint limiting the sum of alkaline oxides in the glass to $19.3 \mathrm{wt} \%$ or less. For glasses containing at least $4 \mathrm{wt} \% \mathrm{Al}_{2} \mathrm{O}_{3}$ (not including uncertainties), there is not an implied upper alkali constraint over the glass compositional regions previously tested. These constraints were implemented in PCCS based on the recommendations by Edwards et al. ${ }^{17}$

It should also be noted that a $\mathrm{SO}_{4}{ }^{2-}$ solubility limit of $0.4 \mathrm{wt} \%$ was used in these assessments. It is anticipated that the sulfate limit for the SB5 system will be the same as that for the Sludge Batch 4 (SB4) system: $0.60 \mathrm{wt} \% \mathrm{SO}_{4}{ }^{2-}$ or $0.88 \mathrm{wt} \% \mathrm{Na}_{2} \mathrm{SO}_{4}$ in glass. This potential increase in the $\mathrm{SO}_{4}{ }^{2-}$ limit should be taken into consideration if any frit/sludge systems are found to be restricted by the $0.4 \mathrm{wt} \% \mathrm{SO}_{4}{ }^{2-}$ constraint in the Nominal Stage assessment.

The Nominal Stage results for the three SB5 projections combined with the 19,305 frits were evaluated and a smaller number of frits were down-selected for additional study. Two additional criteria were used in order to reduce the number of candidate frit compositions to a reasonable amount. First, only frits that provided operating windows of at least 15 percentage points (in terms of wt \% WL) were considered. Second, the frits could not fail the nepheline constraint at WLs below $45 \mathrm{wt} \%$. Applying these criteria left 44 potential frit compositions for SB5 Case B, 60 potential frit compositions for SB5 Case C, and 98 potential frit compositions for SB5 Case F.

\footnotetext{
${ }^{a}$ Note that SRNL has previously recommended that the homogeneity and high frit constraints be removed for sludge only processing in the DWPF. ${ }^{16}$ However, these changes have not yet been implemented in PCCS.
} 
A final set of criteria was applied in order to identify a small number of candidate frits for each SB5 composition projection. The candidate frits were chosen based on:

- Relatively high $\mathrm{B}_{2} \mathrm{O}_{3}$ and $\mathrm{Na}_{2} \mathrm{O}$ concentrations, which are expected to improve melt rate,

- Minimal $\mathrm{Li}_{2} \mathrm{O}$ concentrations to reduce frit cost, and

- Minimal $\mathrm{CaO}$ concentrations to avoid potential crystallization of calcium-rich phases in the melter.

These criteria aided in the selection of three candidate frits for each SB5 projection. However, it should be noted that there were more than three frits available for each of the SB5 projections that met all of the above criteria. Therefore, the number of frits chosen as candidates represents a number that was considered reasonable for performing the paper study assessments rather than a complete set of the available options.

The compositions of the three candidate frits selected for each SB5 composition projection are given in Table 5-1. Note that the criteria applied in selecting the frit compositions somewhat restrict the compositional flexibility of the candidate frits for each individual SB5 composition projection, which may limit the ability to further tailor the frit for improved melt rate. The candidate frits cover a relatively narrow range of $\mathrm{B}_{2} \mathrm{O}_{3}$ concentrations, which may hinder the ability to use $\mathrm{B}_{2} \mathrm{O}_{3}$ to improve melt rate and/or suppress nepheline crystallization. In general, the concentration of $\mathrm{Li}_{2} \mathrm{O}$ in the candidate frits is relatively high - even though candidates with minimal $\mathrm{Li}_{2} \mathrm{O}$ concentrations were chosen - as compared to the frits used in recent DWPF processing (e.g., Frits 418 and 510 each contain 8 wt \% $\mathrm{Li}_{2} \mathrm{O}$ ). The concentration of $\mathrm{Na}_{2} \mathrm{O}$ in the candidate frits is relatively low (e.g., Frit 418 contains 8 wt \% $\mathrm{Na}_{2} \mathrm{O}$, and Frit 510 contains 9 wt $\% \mathrm{Na}_{2} \mathrm{O}$ ).

Table 5-1. Candidate frits for SB5 down-selected from the Nominal Stage results.

\begin{tabular}{|c|c|c|c|c|c|c|c|}
\hline $\begin{array}{c}\text { SB5 Composition } \\
\text { Projection }\end{array}$ & Frit ID & $\begin{array}{c}\mathrm{B}_{2} \mathrm{O}_{3} \\
(\mathrm{wt} \%) \\
\end{array}$ & $\begin{array}{c}\mathrm{CaO} \\
\text { (wt \%) }\end{array}$ & $\begin{array}{c}\mathbf{L i}_{2} \mathbf{O} \\
(\mathrm{wt} \%) \\
\end{array}$ & $\begin{array}{c}\text { MgO } \\
\text { (wt \%) }\end{array}$ & $\begin{array}{c}\mathrm{Na}_{2} \mathrm{O} \\
\text { (wt \%) }\end{array}$ & $\begin{array}{r}\mathrm{SiO}_{2} \\
(\mathrm{wt} \%) \\
\end{array}$ \\
\hline \multirow{3}{*}{ Case B } & B-1 & 10 & 2 & 12 & 0 & 2 & 74 \\
\hline & B-2 & 8 & 0 & 10 & 0 & 4 & 78 \\
\hline & B-3 & 9 & 0 & 12 & 0 & 3 & 76 \\
\hline \multirow{3}{*}{ Case C } & $\mathrm{C}-1$ & 8 & 2 & 10 & 0 & 5 & 75 \\
\hline & $\mathrm{C}-2$ & 8 & 0 & 10 & 0 & 5 & 76 \\
\hline & C-3 & 8 & 0 & 9 & 0 & 7 & 76 \\
\hline \multirow{3}{*}{ Case F } & F-1 & 10 & 0 & 12 & 0 & 3 & 75 \\
\hline & $\mathrm{F}-2$ & 11 & 2 & 11 & 0 & 3 & 73 \\
\hline & F-3 & 8 & 0 & 11 & 0 & 5 & 76 \\
\hline
\end{tabular}

A summary of the Nominal Stage assessment for the three candidate frits identified for SB5 Case $B$ is given in Table 5-2. The available operating windows range from 15 to 18 percentage points in terms of available WLs. The minimum WL was limited for Frits B-2 and B-3 by the homogeneity constraint (at the Property Acceptability Region). The maximum WL was limited by liquidus temperature predictions. The liquidus temperature constraint relates to the DWPF process and does not necessarily affect waste form performance. 
WSRC-STI-2007-00690

Revision 0

Table 5-2. Summary of Nominal Stage results for SB5 Case B with the candidate frits.

\begin{tabular}{|l|c|c|c||}
\hline & B-1 & B-2 & B-3 \\
\hline $\begin{array}{l}\text { Operating } \\
\text { Window } \\
\text { (\% WL) }\end{array}$ & $25-43$ & $27-43$ & $27-42$ \\
\hline $\begin{array}{l}\text { Lower Limiting } \\
\text { Constraint(s) }\end{array}$ & none & Homg & Homg \\
\hline $\begin{array}{l}\text { Upper Limiting } \\
\text { Constraint(s) }\end{array}$ & TL & TL & TL \\
\hline
\end{tabular}

A summary of the Nominal Stage assessment for the three candidate frits identified for SB5 Case $\mathrm{C}$ is given in Table 5-3. The available operating windows range from 15 to 17 percentage points in terms of available WLs. The minimum WL was limited by the homogeneity constraint for Frits C-2 and C-3. The maximum WL was limited by liquidus temperature predictions. The avoidance of nepheline as a limiting constraint for SB5 Case $\mathrm{C}$ is due to the reduced concentrations of $\mathrm{Al}_{2} \mathrm{O}_{3}$ and $\mathrm{Na}_{2} \mathrm{O}$ in this composition projection, as well as the increased $\mathrm{SiO}_{2}$ concentration. This could be considered beneficial for DWPF processing since the constraint limiting the upper WL for these frits combined with SB5 Case C is process related, rather than waste form affecting.

Table 5-3. Summary of Nominal Stage results for SB5 Case $\mathrm{C}$ with the candidate frits.

\begin{tabular}{||l|c|c|c||}
\hline & C-1 & C-2 & C-3 \\
\hline $\begin{array}{l}\text { Operating } \\
\text { Window (\% WL) }\end{array}$ & $25-42$ & $28-43$ & $28-43$ \\
\hline $\begin{array}{l}\text { Lower Limiting } \\
\text { Constraint(s) }\end{array}$ & none & Homg & Homg \\
\hline $\begin{array}{l}\text { Upper Limiting } \\
\text { Constraint(s) }\end{array}$ & TL & TL & TL \\
\hline
\end{tabular}

A summary of the Nominal Stage assessment for the three candidate frits identified for SB5 Case $\mathrm{F}$ is given in Table 5-4. The available operating windows range from 14 to 16 percentage points in terms of available WLs. The minimum WL was limited by the homogeneity constraint for Frits F-1 and F-3. The maximum WL was limited by liquidus temperature predictions, as well as predictions of nepheline crystallization for Frit F-3. Again, the liquidus temperature constraint relates to the DWPF process and does not necessarily affect waste form performance. However, nepheline formation can reduce the durability of the glass product and is of greater concern.

Table 5-4. Summary of Nominal Stage results for SB5 Case F with the candidate frits.

\begin{tabular}{||l|c|c|c||}
\hline & F-1 & F-2 & F-3 \\
\hline $\begin{array}{l}\text { Operating } \\
\text { Window (\% WL) }\end{array}$ & $28-42$ & $25-41$ & $28-44$ \\
\hline $\begin{array}{l}\text { Lower Limiting } \\
\text { Constraint(s) }\end{array}$ & Homg & none & Homg \\
\hline $\begin{array}{l}\text { Upper Limiting } \\
\text { Constraint(s) }\end{array}$ & TL & TL & TL, Neph \\
\hline
\end{tabular}


Overall, the Nominal Stage results for the three SB5 compositions with their respective candidate frits are quite similar. The operating windows are relatively wide, and are mostly limited by process related constraints, with only one frit/sludge combination being limited by a waste form affecting constraint. The complete results of the Nominal Stage assessment for the candidate frits combined with SB5 Cases B, C and F are given in Tables A1, A2 and A3, respectively, in Appendix A.

\subsection{Variation Stage Assessments}

The focus of the Variation Stage assessments is to evaluate the performance of a small number of candidate frits when the anticipated compositional variation is applied to the sludge systems of interest. Variation was applied to the components of each projection based on their concentrations. ${ }^{a}$ For the major components $-\mathrm{Al}_{2} \mathrm{O}_{3}, \mathrm{Fe}_{2} \mathrm{O}_{3}, \mathrm{Na}_{2} \mathrm{O}$ and $\mathrm{U}_{3} \mathrm{O}_{8}-\mathrm{a}$ variation of $7.5 \%$ of each component's concentration was applied. Other important components with lower concentrations were treated individually. A variation of $0.25 \mathrm{wt} \%$ was applied to $\mathrm{CaO}, \mathrm{MgO}$, $\mathrm{MnO}$ and NiO. A variation of $0.1 \mathrm{wt} \%$ was applied to $\mathrm{SO}_{4}{ }^{2-}$ and a variation of $0.5 \mathrm{wt} \%$ was applied to $\mathrm{SiO}_{2}$. The remaining sludge components were grouped into a category called 'Others'. A variation of $0.25 \mathrm{wt} \%$ was applied to the total concentration of the 'Others' components. The compositions of SB5 Cases B, C and F with the variation applied are given in Table 6-1.

Table 6-1. Compositions of SB5 Cases B, C and F with variation applied.

\begin{tabular}{||c|c|c|c|c|c|c|c||}
\hline \multirow{2}{*}{ Component } & \multirow{2}{*}{ Variation } & \multicolumn{2}{|c|}{ SB5 Case B } & \multicolumn{2}{c|}{ SB5 Case C } & \multicolumn{2}{c||}{ SB5 Case F } \\
\cline { 3 - 8 } & & $\begin{array}{c}\text { Min. } \\
\text { (wt \%) }\end{array}$ & $\begin{array}{c}\text { Max. } \\
\text { (wt \%) }\end{array}$ & $\begin{array}{c}\text { Min. } \\
\text { (wt \%) }\end{array}$ & $\begin{array}{c}\text { Max. } \\
\text { (wt \%) }\end{array}$ & $\begin{array}{c}\text { Min. } \\
\text { (wt \%) }\end{array}$ & $\begin{array}{c}\text { Max. } \\
\text { (wt \%) }\end{array}$ \\
\hline $\mathrm{Al}_{2} \mathrm{O}_{3}$ & $7.5 \%$ & 26.787 & 31.131 & 23.014 & 26.746 & 25.133 & 29.209 \\
\hline $\mathrm{CaO}$ & $0.25 \mathrm{wt} \%$ & 1.531 & 2.031 & 1.714 & 02.214 & 1.632 & 2.132 \\
\hline $\mathrm{Fe}_{2} \mathrm{O}_{3}$ & $7.5 \%$ & 21.492 & 24.977 & 23.706 & 27.550 & 22.641 & 26.313 \\
\hline $\mathrm{MgO}$ & $0.25 \mathrm{wt} \%$ & 0.927 & 1.427 & 1.048 & 1.548 & 0.989 & 1.489 \\
\hline $\mathrm{MnO}$ & $0.25 \mathrm{wt} \%$ & 4.608 & 5.108 & 5.109 & 5.609 & 4.872 & 5.372 \\
\hline $\mathrm{Na}_{2} \mathrm{O}$ & $7.5 \%$ & 22.959 & 26.682 & 22.367 & 25.994 & 22.403 & 26.036 \\
\hline $\mathrm{NiO}^{2}$ & $0.25 \mathrm{wt} \%$ & 2.479 & 2.979 & 2.759 & 3.259 & 2.612 & 3.112 \\
\hline $\mathrm{SO}_{4}^{2-}$ & $0.1 \mathrm{wt} \%$ & 0.629 & 0.829 & 0.661 & 0.861 & 0.646 & 0.846 \\
\hline $\mathrm{SiO}_{2}$ & $0.5 \mathrm{wt} \%$ & 1.385 & 2.385 & 1.580 & 2.580 & 1.469 & 2.469 \\
\hline $\mathrm{U}_{3} \mathrm{O}_{8}$ & $7.5 \%$ & 6.875 & 7.990 & 7.583 & 8.813 & 7.212 & 8.382 \\
\hline $\mathrm{Others}^{2-} \%$ & $0.25 \mathrm{wt} \%$ & 1.159 & 1.659 & 1.299 & 1.799 & 2.266 & 2.766 \\
\hline
\end{tabular}

Statistical mixture experimental design methods were used to obtain an initial set of feasible sludge compositions based on the variation applied to SB5 Cases B, C and F. These methods included algorithms that were used to determine the extreme vertices (EVs) of the sludge region (the bounding compositions) for each case. After the EVs were determined for each sludge region, the Variation Stage assessments were made over the same waste loading interval (25 to 60 wt \%) using the DWPF PCCS models. Acceptable predicted properties for this assessment were based on satisfying the more restrictive Measurement Acceptability Region (MAR) limits of PCCS - consistent with the Nominal Stage assessment. All MAR constraints were based on the current PCCS limits. ${ }^{2}$

\footnotetext{
${ }^{a}$ The amount of compositional variation applied to each individual component of a projected sludge batch composition has been refined by SRNL through frit development efforts for Sludge Batches 3 and 4 . Based on the success of these prior Variation Stage assessments in guiding optimal frit selection, the same amount of variation was applied to the SB5 projections in this study.
} 
A summary of the Variation Stage results for SB5 Case B with its three candidate frits is given in Table 6-2. The operating windows indicate regions where all of the EVs satisfied the MAR criteria when combined with the given frit at the indicated WL. As is typically the case, the projected operating windows are reduced as compared to the Nominal Stage assessment. The operating windows for SB5 Case B range from 6 to 14 percentage points. The minimum WLs are limited by the homogeneity and high viscosity constraints. The maximum WLs are limited by the liquidus temperature and low viscosity constraints.

Table 6-2. Summary of Variation Stage results for SB5 Case B with the candidate frits.

\begin{tabular}{|l|c|c|c||}
\hline & Frit B-1 & Frit B-2 & Frit B-3 \\
\hline $\begin{array}{l}\text { Operating } \\
\text { Window } \\
\text { (\% WL) }\end{array}$ & $26-40$ & $29-41$ & $33-39$ \\
\hline $\begin{array}{l}\text { Lower Limiting } \\
\text { Constraint(s) }\end{array}$ & Homg & Homg & highv \\
\hline $\begin{array}{l}\text { Upper Limiting } \\
\text { Constraint(s) }\end{array}$ & TL, lowv & TL & TL \\
\hline
\end{tabular}

A summary of the Variation Stage results for SB5 Case C with its three candidate frits is given in Table 6-3. The widths of the operating windows range from 8 to 12 percentage points. The minimum WLs are limited by the homogeneity constraint. The maximum WLs are limited by the liquidus temperature constraint for Frits C-1 and C-3, and by the low viscosity constraint for Frit C-2.

Table 6-3. Summary of Variation Stage results for SB5 Case C with the candidate frits.

\begin{tabular}{||l|c|c|c||}
\hline & Frit C-1 & Frit C-2 & Frit C-3 \\
\hline $\begin{array}{l}\text { Operating } \\
\text { Window } \\
\text { (\% WL) }\end{array}$ & $27-39$ & $31-39$ & $31-41$ \\
\hline $\begin{array}{l}\text { Lower Limiting } \\
\text { Constraint(s) }\end{array}$ & Homg & Homg & Homg \\
\hline $\begin{array}{l}\text { Upper Limiting } \\
\text { Constraint(s) }\end{array}$ & TL & lowv & TL \\
\hline
\end{tabular}

A summary of the Variation Stage results for SB5 Case F with its three candidate frits is given in Table 6-4. The widths of the operating windows range from 8 to 13 percentage points. The minimum WLs are limited by the homogeneity constraint. The maximum WLs are limited by the low viscosity constraint, as well as the liquidus temperature constraint for Frits F-2 and F-3.

Table 6-4. Summary of Variation Stage results for SB5 Case F with the candidate frits.

\begin{tabular}{|l|c|c|c||}
\hline & Frit F-1 & Frit F-2 & Frit F-3 \\
\hline $\begin{array}{l}\text { Operating } \\
\text { Window } \\
\text { (\% WL) }\end{array}$ & $30-38$ & $26-39$ & $30-41$ \\
\hline $\begin{array}{l}\text { Lower Limiting } \\
\text { Constraint(s) }\end{array}$ & Homg & Homg & Homg \\
\hline $\begin{array}{l}\text { Upper Limiting } \\
\text { Constraint(s) }\end{array}$ & lowv & TL, lowv & TL, lowv \\
\hline \hline
\end{tabular}


The complete Variation Stage results for SB5 Cases B, C and F are included in Tables A4, A5 and A6, respectively, in Appendix A. The results indicate that there is a reduction in the operating window width for each frit/sludge combination. This response is typical when variation is applied to a sludge composition projection and the magnitude of the reduction is consistent with previous studies. ${ }^{14,15,18,19}$ For each SB5 projection, there are candidate frits available that appear to be sufficiently robust to variation in sludge composition. The frits continue to provide adequate operating windows (assuming DWPF will process SB5 at a target WL of 34-38 wt \%) that are limited by process related - rather than waste form affecting - constraints.

By relaxing some of the criteria used earlier when down-selecting frit compositions from the Nominal Stage assessment results, it may be possible to identify other frit compositions with which the Variation Stage assessment would predict wider operating windows. However, adjusting these criteria may lead to frit/sludge systems that are limited by waste form affecting constraints.

It is important to note that these paper study results do not include any predictions of melt rate performance. Experimental studies are used to provide melt rate data to aid in any frit recommendation decisions. 
WSRC-STI-2007-00690

Revision 0

\subsection{Summary}

Composition projections for SB5 were developed, based on a modeling approach at SRNL, to evaluate possible impacts of the Al-dissolution process on the availability of viable frit compositions for vitrification at the DWPF. The study included two projected SB5 compositions that bound potential outcomes (or degrees of effectiveness) of the Al-dissolution process, as well as a nominal SB5 composition projection based on the results of the recent Al-dissolution demonstration at SRNL. The three SB5 projections were the focus of a two-stage paper study assessment.

A Nominal Stage assessment combined each of the SB5 composition projections with an array of 19,305 frit compositions over a wide range of WL values and evaluated them against the DWPF process control models. The Nominal Stage results allowed for the down-selection of a small number of frits that provided reasonable projected operating windows (typically 27 to $42 \mathrm{wt} \%$ WL). The frit/sludge systems were mostly limited by process related constraints, with only one system being limited by predictions of nepheline crystallization, a waste form affecting constraint. The criteria applied in selecting the frit compositions somewhat restricted the compositional flexibility of the candidate frits for each individual SB5 composition projection, which may limit the ability to further tailor the frit for improved melt rate.

Variation Stage assessments were then performed using the down-selected frits and the three SB5 composition projections with variation applied to each sludge component. The Variation Stage results showed that the operating windows were reduced in width, as expected when variation in the sludge composition is applied. However, several of the down-selected frits exhibited a relatively high degree of robustness to the applied sludge variation, providing WL windows of approximately 30 to $39 \mathrm{wt} \%$. The maximum WLs were limited by processing constraints, liquidus temperature and low viscosity, rather than a waste form affecting constraint (e.g., nepheline crystallization) in the Variation Stage assessments.

These paper study assessments have identified candidate frits which, when combined with the current, projected SB5 compositions after Al-dissolution, have projected operating windows that should be reasonable for DWPF processing. Changes in the SB5 composition are anticipated as the data on the actual Al-dissolution effectiveness and Tank 7 transfer mass become available and, will require additional paper study assessments as well as experimental frit development studies. The frits identified in this study provide insight into potential processing windows but are not the recommended frits for SB5 vitrification in DWPF. No information regarding melt rate can be inferred from the paper study results. Experimental studies to evaluate this critical factor in DWPF processing will need to be performed before a frit recommendation could be made for any projected sludge composition. 
WSRC-STI-2007-00690

Revision 0

\subsection{References}

1. Hay, M. S., J. M. Pareizs, C. J. Bannochie, M. E. Stone, D. R. Click and D. J. McCabe, "Characterization and Aluminum Dissolution Demonstration with a 3 Liter Tank 51H Sample," U.S. Department of Energy Report WSRC-STI-2007-00697, Revision 0, Washington Savannah River Company, Aiken, SC (2008).

2. Edwards, T. B., K. G. Brown and R. L. Postles, "SME Acceptability Determination for DWPF Process Control," U.S. Department of Energy Report WSRC-TR-95-00364, Revision 5, Washington Savannah River Company, Aiken, SC (2006).

3. Peeler, D. K. and T. B. Edwards, "Frit Development for Sludge Batch 3," U.S. Department of Energy Report WSRC-TR-2002-00491, Revision 0, Westinghouse Savannah River Company, Aiken, SC (2002).

4. Bannochie, C. J., M. S. Hay, J. M. Pareizs and D. K. Peeler, "Technology Demonstration of Sludge Mass Reduction via Aluminum Dissolution: Task Technical and Quality Assurance Plan," U.S. Department of Energy Report WSRC-RP-2007-00512, Revision 0, Washington Savannah River Company, Aiken, SC (2007).

5. Choi, A. S., "Aluminum Dissolution Flowsheet Modeling in Support of SB5 Frit Development," U.S. Department of Energy Report WSRC-STI-2008-00001, Revision 0, Washington Savannah River Company, Aiken, SC (2008).

6. Pareizs, J. M., C. J. Bannochie, M. J. Barnes, N. E. Bibler, D. R. Click, E. K. Hansen, D. P. Lambert and M. E. Stone, "Demonstration of the DWPF Flowsheet in the SRNL Shielded Cells in Support of Sludge Batch 4 Qualification," U.S. Department of Energy Report WSRC-STI-200700053, Revision 0, Washington Savannah River Company, Aiken, SC (2007).

7. Lambert, D. P. and C. J. Bannochie, "Results from Analysis of Tank 7F Samples Taken in November 2006 and April 2007," U.S. Department of Energy Report SRNL-PSE-2007-00118, Revision 1, Washington Savannah River Company, Aiken, SC (2007).

8. Fox, K. M., T. B. Edwards, D. R. Best, I. A. Reamer and R. J. Workman, "Sludge Batch 5 (SB5): Selection of Candidate Frits and Characterization of Preliminary Glass Systems," U.S. Department of Energy Report WSRC-STI-2007-00418, Revision 0, Washington Savannah River Company, Aiken, SC (2007).

9. Fox, K. M., T. B. Edwards and D. K. Peeler, "Sludge Batch 4 (SB4) After a Tank 40 Decant: Candidate Frits, MAR Assessments, and Glasses for a Variability Study," U.S. Department of Energy Report WSRC-STI-2006-00305, Revision 0, Washington Savannah River Company, Aiken, SC (2006).

10. Fox, K. M., T. B. Edwards, D. K. Peeler, D. R. Best, I. A. Reamer and R. J. Workman, "Durability and Nepheline Crystallization Study for High Level Waste (HLW) Sludge Batch 4 (SB4) Glasses Formulated with Frit 503," U.S. Department of Energy Report WSRC-STI-200600009, Revision 0, Washington Savannah River Company, Aiken, SC (2006).

11. Gillam Jr., J. H., K. M. Fox, T. B. Edwards and D. K. Peeler, "Frit Selection to Support Steklo Metallicheskie Konstruktsii (SMK) Melter Testing with SRNL Feeds," U.S. Department of 
WSRC-STI-2007-00690

Revision 0

Energy Report WSRC-STI-2007-00363, Revision 0, Washington Savannah River Company, Aiken, SC (2007).

12. Peeler, D. K. and T. B. Edwards, "Frit Development Effort for SB4: Nominal and Variation Stage Assessments," U.S. Department of Energy Report WSRC-TR-2005-00372, Revision 0, Westinghouse Savannah River Company, Aiken, SC (2005).

13. Peeler, D. K. and T. B. Edwards, "Frit Development Efforts for Sludge Batch 4: ModelBased Assessments," U.S. Department of Energy Report WSRC-TR-2005-00103, Revision 0, Westinghouse Savannah River Company, Aiken, SC (2005).

14. Peeler, D. K. and T. B. Edwards, "High $\mathrm{B}_{2} \mathrm{O}_{3} / \mathrm{Fe}_{2} \mathrm{O}_{3}$-based Frits: MAR Assessments for Sludge Batch 4 (SB4)," U.S. Department of Energy Report WSRC-TR-2006-00181, Revision 0, Washington Savannah River Company, Aiken, SC (2006).

15. Peeler, D. K. and T. B. Edwards, "Model Based Assessments of the Final SB4 Projections Compositions Leading to the Frit Recommendation," U.S. Department of Energy Report WSRCTR-2006-00269, Revision 0, Washington Savannah River Company, Aiken, SC (2006).

16. Herman, C. C., T. B. Edwards, D. R. Best, D. M. Marsh and R. J. Workman, "Reduction of Constraints: Phase 2 Experimental Assessment for Sludge-Only Processing," U.S. Department of Energy Report WSRC-TR-2002-00482, Revision 0, Westinghouse Savannah River Company, Aiken, SC (2002).

17. Edwards, T. B. and K. G. Brown, "Evaluating the Glasses Batched for the Tank 42 Variability Study," U.S. Department of Energy Report SRT-SCS-98-017, Revision 0, Westinghouse Savannah River Company, Aiken, SC (1998).

18. Peeler, D. K. and T. B. Edwards, "Model Based Assessments for SB4 Washing Options: 1.2M Batch/0.91M Blend and 1.4M Batch/0.96M Blend," U.S. Department of Energy Report WSRC-STI-2006-00006, Revision 0, Washington Savannah River Company, Aiken, SC (2006).

19. Peeler, D. K. and T. B. Edwards, "Model Based Assessments for the Baseline Sludge Batch 4 (Case 15C) Flowsheet," U.S. Department of Energy Report WSRC-TR-2006-00049, Revision 0, Washington Savannah River Company, Aiken, SC (2006). 
WSRC-STI-2007-00690

Revision 0

Appendix A

Complete Results for the Nominal and Variation Stage Assessments 
WSRC-STI-2007-00690

Revision 0

Table A1. Complete Nominal Stage results for Sludge Case B with Frits B-1, B-2 and B-3.

\begin{tabular}{|c|c|c|c|}
\hline 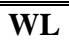 & Frit B-1 & Frit B-2 & Frit B-3 \\
\hline 25 & & Homg hFrit & highv Homg hFrit \\
\hline 26 & & Homg & highv Homg \\
\hline \multicolumn{4}{|l|}{27} \\
\hline \multicolumn{4}{|l|}{28} \\
\hline \multicolumn{4}{|l|}{29} \\
\hline \multicolumn{4}{|l|}{30} \\
\hline \multicolumn{4}{|l|}{31} \\
\hline \multicolumn{4}{|l|}{32} \\
\hline \multicolumn{4}{|l|}{33} \\
\hline \multicolumn{4}{|l|}{34} \\
\hline \multicolumn{4}{|l|}{35} \\
\hline \multicolumn{4}{|l|}{36} \\
\hline \multicolumn{4}{|l|}{37} \\
\hline \multicolumn{4}{|l|}{38} \\
\hline \multicolumn{4}{|l|}{39} \\
\hline \multicolumn{4}{|l|}{40} \\
\hline \multicolumn{4}{|l|}{41} \\
\hline \multicolumn{4}{|l|}{42} \\
\hline 43 & & & TL \\
\hline 44 & $\mathrm{TL}$ & $\mathrm{TL}$ & TL \\
\hline 45 & TL Neph & TL Neph & TL Neph \\
\hline 46 & TL lowv Neph & TL Neph & TL Neph \\
\hline 47 & TL lowv Neph & TL Neph & TL Neph \\
\hline 48 & TL lowv Neph & TL Neph & TL Neph \\
\hline 49 & TL lowv Neph & TL Neph & TL Neph \\
\hline 50 & TL lowv Neph & TL Neph & TL Neph \\
\hline 51 & TL lowv Neph & TL Neph & TL Neph \\
\hline 52 & TL lowv Neph & TL Neph & TL Neph \\
\hline 53 & TL lowv Neph & TL Neph & TL Neph \\
\hline 54 & TL lowv Neph & TL Neph & TL Neph \\
\hline 55 & TL lowv SO4 Neph & TL lowv SO4 Neph & TL SO4 Neph \\
\hline 56 & TL lowv SO4 Neph & TL lowv SO4 Neph & TL SO4 Neph \\
\hline 57 & TL lowv SO4 Neph & TL lowv SO4 Neph & TL lowv SO4 Neph \\
\hline 58 & TL lowv SO4 Neph & TL lowv SO4 Neph & TL lowv SO4 Neph \\
\hline 59 & TL lowv SO4 Neph & TL lowv SO4 Neph & TL lowv SO4 Neph \\
\hline 60 & TL lowv SO4 Neph & TL lowv SO4 Neph & TL lowv SO4 Neph \\
\hline
\end{tabular}


WSRC-STI-2007-00690

Revision 0

Table A2. Complete Nominal Stage results for Sludge Case C with Frits C-1, C-2 and C-3.

\begin{tabular}{|c|c|c|c|}
\hline WL & Frit C-1 & Frit C-2 & Frit C-3 \\
\hline 25 & & Homg hFrit & Homg hFrit \\
\hline 26 & & Homg & Homg \\
\hline 27 & & Homg & Homg \\
\hline \multicolumn{4}{|l|}{28} \\
\hline \multicolumn{4}{|l|}{29} \\
\hline \multicolumn{4}{|l|}{30} \\
\hline \multicolumn{4}{|l|}{31} \\
\hline \multicolumn{4}{|l|}{32} \\
\hline \multicolumn{4}{|l|}{33} \\
\hline \multicolumn{4}{|l|}{34} \\
\hline \multicolumn{4}{|l|}{35} \\
\hline \multicolumn{4}{|l|}{36} \\
\hline \multicolumn{4}{|l|}{37} \\
\hline \multicolumn{4}{|l|}{38} \\
\hline \multicolumn{4}{|l|}{39} \\
\hline \multicolumn{4}{|l|}{40} \\
\hline \multicolumn{4}{|l|}{41} \\
\hline \multicolumn{4}{|l|}{42} \\
\hline 43 & $\mathrm{TL}$ & & \\
\hline 44 & $\mathrm{TL}$ & $\mathrm{TL}$ & $\mathrm{TL}$ \\
\hline 45 & TL Neph & TL lowv & TL Neph \\
\hline 46 & TL Neph & TL lowv Neph & TL Neph \\
\hline 47 & TL lowv Neph & TL lowv Neph & TL Neph \\
\hline 48 & TL lowv Neph & TL lowv Neph & TL lowv Neph \\
\hline 49 & TL lowv Neph & TL lowv Neph & TL lowv Neph \\
\hline 50 & TL lowv Neph & TL lowv Neph & TL lowv Neph \\
\hline 51 & TL lowv Neph & TL lowv Neph & TL lowv Neph \\
\hline 52 & TL lowv Neph & TL lowv Neph & TL lowv Neph \\
\hline 53 & TL lowv SO4 Neph & TL lowv SO4 Neph & TL lowv SO4 Neph \\
\hline 54 & TL lowv SO4 Neph & TL lowv SO4 Neph & TL lowv SO4 Neph \\
\hline 55 & TL lowv SO4 Neph & TL lowv SO4 Neph & TL lowv SO4 Neph \\
\hline 56 & TL lowv SO4 Neph & TL lowv SO4 Neph & TL lowv SO4 Neph \\
\hline 57 & TL lowv SO4 Cr2O3 Neph & TL lowv SO4 Cr2O3 Neph & TL lowv SO4 Cr2O3 Neph \\
\hline 58 & TL lowv SO4 Cr2O3 Neph & TL lowv SO4 Cr2O3 Neph & TL lowv SO4 Cr2O3 Neph \\
\hline 59 & TL lowv SO4 Cr2O3 Neph & TL lowv SO4 Cr2O3 Neph & TL lowv SO4 Cr2O3 Neph \\
\hline 60 & TL lowv SO4 Cr2O3 Neph & TL lowv SO4 Cr2O3 Neph & TL lowv SO4 Cr2O3 Neph \\
\hline
\end{tabular}


WSRC-STI-2007-00690

Revision 0

Table A3. Complete Nominal Stage results for Sludge Case F with Frits F-1, F-2 and F-3.

\begin{tabular}{|c|c|c|c|}
\hline "WL & Frit F-1 & Frit F-2 & Frit F-3 \\
\hline 25 & Homg hFrit & & Homg hFrit \\
\hline 26 & Homg & & Homg \\
\hline 27 & Homg & & Homg \\
\hline \multicolumn{4}{|l|}{28} \\
\hline \multicolumn{4}{|l|}{29} \\
\hline \multicolumn{4}{|l|}{30} \\
\hline \multicolumn{4}{|l|}{31} \\
\hline \multicolumn{4}{|l|}{32} \\
\hline \multicolumn{4}{|l|}{33} \\
\hline \multicolumn{4}{|l|}{34} \\
\hline \multicolumn{4}{|l|}{35} \\
\hline \multicolumn{4}{|l|}{36} \\
\hline \multicolumn{4}{|l|}{37} \\
\hline \multicolumn{4}{|l|}{38} \\
\hline \multicolumn{4}{|l|}{39} \\
\hline \multicolumn{4}{|l|}{40} \\
\hline \multicolumn{4}{|l|}{41} \\
\hline 42 & & $\mathrm{TL}$ & \\
\hline 43 & TL & TL & \\
\hline 44 & TL lowv & TL & \\
\hline 45 & TL lowv Neph & TL lowv Neph & TL Neph \\
\hline 46 & TL lowv Neph & TL lowv Neph & TL Neph \\
\hline 47 & TL lowv Neph & TL lowv Neph & TL lowv Neph \\
\hline 48 & TL lowv Neph & TL lowv Neph & TL lowv Neph \\
\hline 49 & TL lowv Neph & TL lowv Neph & TL lowv Neph \\
\hline 50 & TL lowv Neph & TL lowv Neph & TL lowv Neph \\
\hline 51 & TL lowv Neph & TL lowv Neph & TL lowv Neph \\
\hline 52 & TL lowv Neph & TL lowv Neph & TL lowv Neph \\
\hline 53 & TL lowv Neph & TL lowv Neph & TL lowv Neph \\
\hline 54 & TL lowv SO4 Neph & TL lowv SO4 Neph & TL lowv SO4 Neph \\
\hline 55 & TL lowv SO4 Neph & TL lowv SO4 Neph & TL lowv SO4 Neph \\
\hline 56 & TL lowv SO4 Neph & TL lowv SO4 Neph & TL lowv SO4 Neph \\
\hline 57 & TL lowv SO4 Neph & TL lowv SO4 Neph & TL lowv SO4 Neph \\
\hline 58 & TL lowv SO4 Neph & TL lowv SO4 Neph & TL lowv SO4 Neph \\
\hline 59 & TL lowv SO4 Neph & TL lowv SO4 Neph & TL lowv SO4 Neph \\
\hline 60 & TL lowv SO4 Cr2O3 Neph & TL lowv SO4 Cr2O3 Neph & TL lowv SO4 Cr2O3 Neph \\
\hline
\end{tabular}


WSRC-STI-2007-00690

Revision 0

Table A4. Results of the Variation Stage assessment for SB5 Case B with the candidate frits.

\begin{tabular}{|c|c|c|c|c|c|c|}
\hline \multirow[b]{2}{*}{ WL } & \multicolumn{2}{|r|}{ Frit B-1 } & \multicolumn{2}{|r|}{ Frit B-2 } & \multicolumn{2}{|r|}{ Frit B-3 } \\
\hline & $\begin{array}{l}\text { Percent } \\
\text { of EVs }\end{array}$ & Limiting Constraint(s) & $\begin{array}{l}\text { Percent } \\
\text { of EVs }\end{array}$ & Limiting Constraint(s) & $\begin{array}{l}\text { Percent } \\
\text { of EVs }\end{array}$ & Limiting Constraint(s) \\
\hline 25 & 99.6 & Homg & 19.4 & Homg hFrit highv & 0.0 & Homg hFrit highv \\
\hline 26 & 100.0 & & 36.1 & Homg hFrit & 0.8 & Homg hFrit highv \\
\hline 27 & 100.0 & & 83.3 & Homg & 38.2 & Homg highv \\
\hline 28 & 100.0 & & 97.7 & Homg & 57.0 & Homg highv \\
\hline 29 & 100.0 & & 100.0 & & 98.1 & highv \\
\hline 30 & 100.0 & & 100.0 & & 83.8 & highv \\
\hline 31 & 100.0 & & 100.0 & & 92.8 & highv \\
\hline 32 & 100.0 & & 100.0 & & 97.9 & highv \\
\hline 33 & 100.0 & & 100.0 & & 100.0 & \\
\hline 34 & 100.0 & & 100.0 & & 100.0 & \\
\hline 35 & 100.0 & & 100.0 & & 100.0 & \\
\hline 36 & 100.0 & & 100.0 & & 100.0 & \\
\hline 37 & 100.0 & & 100.0 & & 100.0 & \\
\hline 38 & 100.0 & & 100.0 & & 100.0 & \\
\hline 39 & 100.0 & & 100.0 & & 100.0 & \\
\hline 40 & 100.0 & & 100.0 & & 99.9 & $\overline{T L}$ \\
\hline 41 & 77.0 & TL lowv & 100.0 & & 95.9 & TL \\
\hline 42 & 61.9 & TL lowv Neph & 96.7 & TL & 88.4 & TL \\
\hline 43 & 27.4 & TL lowv Neph & 74.1 & TL Neph & 62.1 & TL Neph \\
\hline 44 & 5.0 & TL lowv Neph & 45.0 & TL Neph & 36.3 & TL Neph \\
\hline 45 & 0.0 & TL lowv Neph & 3.0 & TL Neph & 1.7 & TL Neph \\
\hline 46 & 0.0 & TL lowv Neph & 0.0 & TL Neph & 0.0 & TL Neph \\
\hline 47 & 0.0 & TL lowv Neph & 0.0 & TL Neph & 0.0 & TL Neph \\
\hline 48 & 0.0 & TL lowv Neph & 0.0 & TL Neph & 0.0 & TL Neph \\
\hline 49 & 0.0 & TL lowv Neph SO4 & 0.0 & TL lowv SO4 Neph & 0.0 & TL SO4 Neph \\
\hline 50 & 0.0 & TL lowv Neph SO4 & 0.0 & TL lowv SO4 Neph & 0.0 & TL SO4 Neph \\
\hline 51 & 0.0 & TL lowv Neph SO4 & 0.0 & TL lowv SO4 Neph & 0.0 & TL lowv SO4 Neph \\
\hline 52 & 0.0 & TL lowv Neph SO4 & 0.0 & TL lowv SO4 Neph & 0.0 & TL lowv SO4 Neph \\
\hline 53 & 0.0 & TL lowv Neph SO4 & 0.0 & TL lowv SO4 Neph & 0.0 & TL lowv SO4 Neph \\
\hline 54 & 0.0 & TL lowv Neph SO4 & 0.0 & TL lowv SO4 Neph & 0.0 & TL lowv SO4 Neph \\
\hline 55 & 0.0 & TL lowv Neph SO4 & 0.0 & TL lowv SO4 Neph & 0.0 & TL lowv SO4 Neph \\
\hline 56 & 0.0 & TL lowv Neph SO4 & 0.0 & TL lowv SO4 Neph & 0.0 & TL lowv SO4 Neph \\
\hline 57 & 0.0 & TL lowv Neph SO4 & 0.0 & TL lowv SO4 Neph & 0.0 & TL lowv SO4 Neph \\
\hline 58 & 0.0 & TL lowv Neph SO4 & 0.0 & TL lowv SO4 Neph & 0.0 & TL lowv SO4 Neph \\
\hline 59 & 0.0 & TL lowv Neph SO4 & 0.0 & TL lowv SO4 Neph & 0.0 & TL lowv SO4 Neph \\
\hline 60 & 0.0 & TL lowv Neph SO4 & 0.0 & TL lowv SO4 Neph & 0.0 & TL lowv SO4 Neph \\
\hline
\end{tabular}


WSRC-STI-2007-00690

Revision 0

Table A5. Results of the Variation Stage assessment for SB5 Case C with the candidate frits.

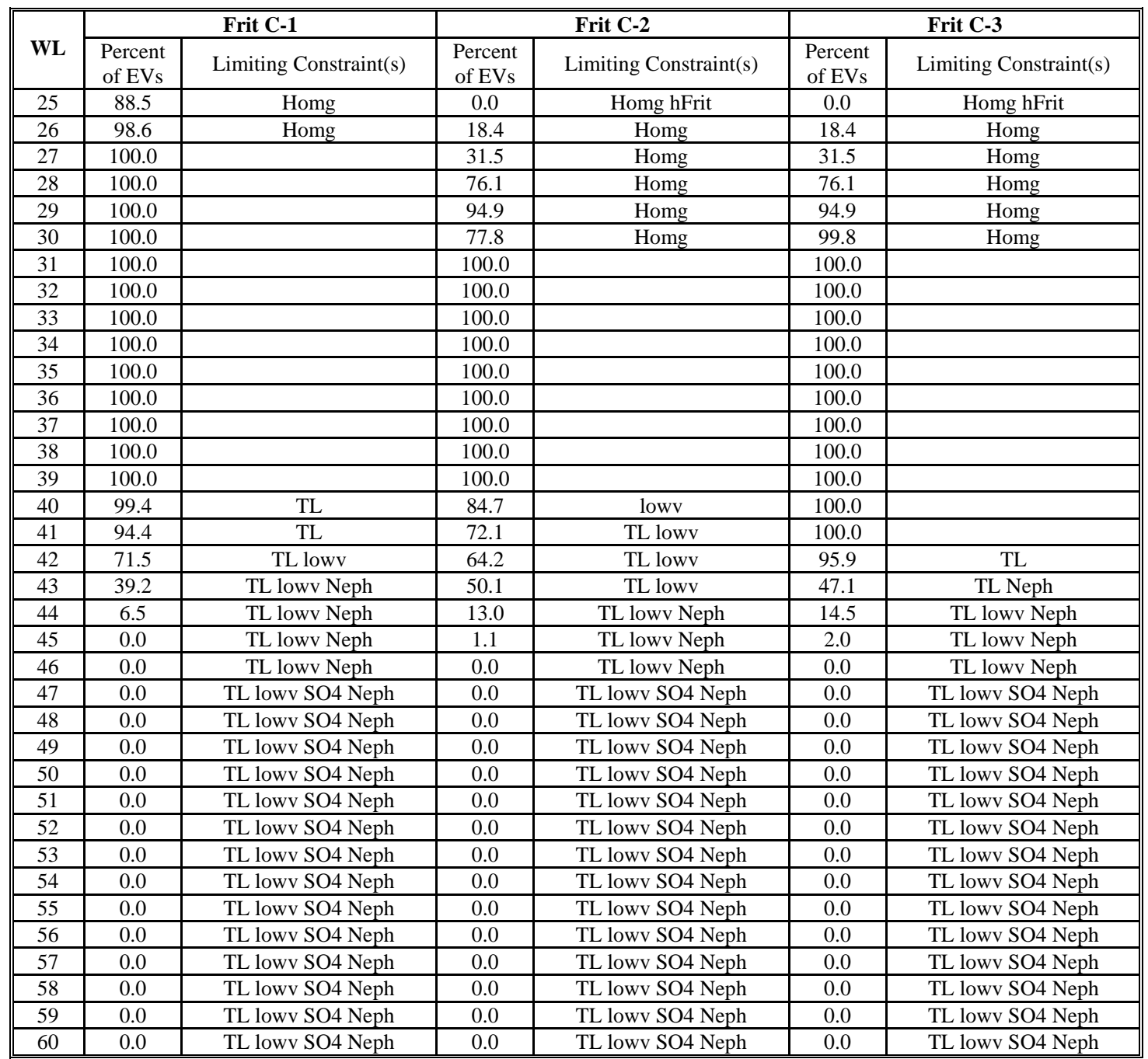


WSRC-STI-2007-00690

Revision 0

Table A6. Results of the Variation Stage assessment for SB5 Case F with the candidate frits.

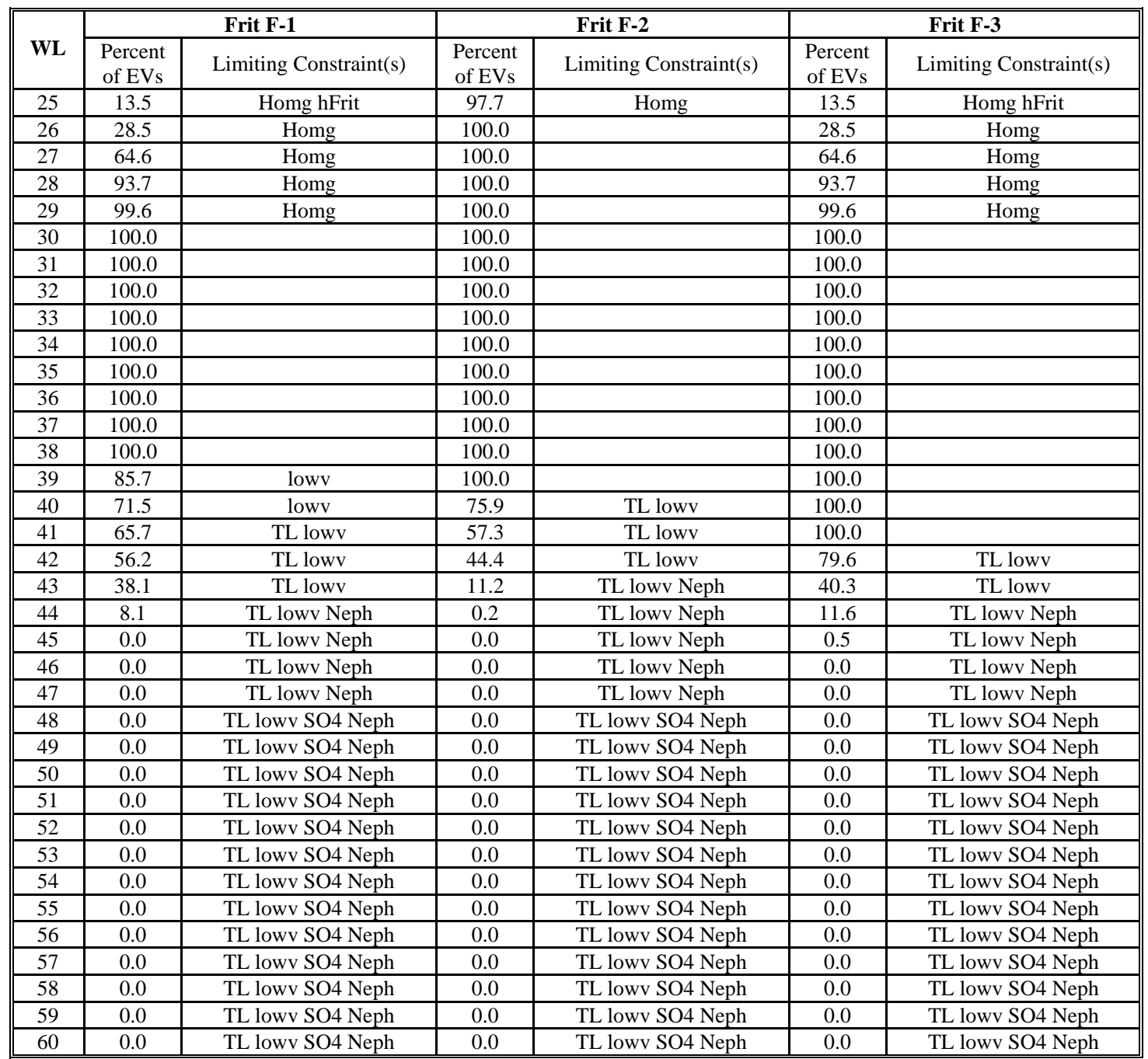


WSRC-STI-2007-00690

Revision 0

This page intentionally left blank. 


\section{Distribution:}
A.B. Barnes, 999-W
D.R. Best, 786-1A
D.B. Burns, 786-5A
D.A. Crowley, 999-W
B.A. Davis, 704-27S
R.E. Edwards, 773-A
T.B. Edwards, 999-W
K.M. Fox, 999-W
J.M. Gillam, 766-H
J.C. Griffin, 773-A
B.A. Hamm, 766-H
C.C. Herman, 999-W
J.F. Iaukea, 704-30S
C.M. Jantzen, 773-A
T.M. Jones, 999-W
M.T. Keefer, 766-H
D.C. Koopman, 999-W
J.E. Marra, 773-A

D.J. McCabe, 773-42A

R.T. McNew, 704-27S

D.H. Miller, 999-W

T.A. Nance, 773-42A

J.D. Newell, 999-W

J.E. Occhipinti, 704-S

D.K. Peeler, 999-W

J.A. Pike, 703-H

F.C. Raszewski, 999-W

J.W. Ray, 704-S

I.A. Reamer, 999-1W

H.B. Shah, 766-H

M.E. Smith, 999-W

M.E. Stone, 999-W

J. Stuberfield, 766-H

P.C. Suggs, 704-S

R.J. Workman, 999-1W

A.L. Youchak, 999-W 